\title{
Influence of temperature on the zoeal development and elemental composition of the cancrid crab, Cancer setosus Molina, 1782 from Pacific South America
}

\author{
Monika Weiss ${ }^{\mathrm{a}, *}$, Olaf Heilmayer ${ }^{\mathrm{a}}$, Thomas Brey ${ }^{\mathrm{a}}$, Sven Thatje ${ }^{\mathrm{b}}$ \\ a Alfred-Wegener-Institut für Polar und Meeresforschung, Am Handelshafen 12, 27570 Bremerhaven, Germany \\ ${ }^{\mathrm{b}}$ National Oceanography Centre, Southampton, School of Ocean and Earth Science, University of Southampton, European Way, Southampton, SO14 3ZH, United Kingdom
}

\section{A R T I C L E I N F O}

Article history:

Received 20 February 2009

Received in revised form 27 April 2009

Accepted 4 June 2009

\section{Keywords:}

Brachyura

Early ontogeny

Elemental composition

El Niño

Hairy crab

Survival rate

\begin{abstract}
A B S T R A C T
Temperature changes during ENSO cause mass mortalities of adult Cancer setosus, but the effects on early life stages are unknown. The influence of temperature on survival, development and biochemical composition was studied in larvae of the hairy crab, C. setosus, from a population off the northern Chilean coast. In rearing experiments conducted at four different temperatures $\left(12,16,20,22{ }^{\circ} \mathrm{C}\right)$, zoeal development was only completed at 16 and $20^{\circ} \mathrm{C}$, after 78 and 36 days, respectively. Instar duration was negatively correlated with temperature. A multiple linear model relating larval body mass (in carbon) to temperature and developmental time suggests that successful larval development is possible within a narrow temperature range only. The biochemical composition, measured as carbon, hydrogen, and nitrogen $(C, H, N)$ content, show in general the typical oscillating changes during the moult cycle of brachyuran crab larvae. However, at high $\left(22^{\circ} \mathrm{C}\right)$ and low $\left(16^{\circ} \mathrm{C}\right)$ temperatures, $\mathrm{CHN}$ values show deviations from the typical pattern, indicating threshold temperatures for larval activity and survival. These findings indicate that the larval development of C. setosus is compromised under conditions of El Niño, with temperatures exceeding the upper thermal temperature tolerance threshold of larvae. Effects of El Niño on early life history stages and recruitment rates should be increasingly taken into account in fisheries management strategies.
\end{abstract}

(c) 2009 Elsevier B.V. All rights reserved.

\section{Introduction}

Most cancrid crabs are found in cold temperate and boreal waters (MacKay, 1943) and provide a huge proportion of crustacean fisheries in those regions (Bennett, 1995; Johnson and Shanks, 2002). Due to their commercial importance population structure and recruitment of cancrid crabs have been the subject of several studies (e. g. Hankin et al., 1997; Eaton et al., 2003; Taggart et al., 2004; Fischer and Thatje, 2008; Fischer et al., 2009). Successful recruitment is based on larval development. Larval hatching normally occurs during spring when food availability (plankton bloom) (Park et al., 2007) and temperatures are favourable for larval growth. This seasonal dependency is not valid for larvae in the highly productive upwelling region of the Humboldt Current, which provides a huge amount of plankton yearround during upwelling periods. The persistent stable temperate conditions in a broad range of the Humboldt Current allow larvae to develop all year round (for review see Fischer and Thatje, 2008). As one of the world's most productive ecosystems, the Humboldt Current supports one of the world's largest fisheries (Bertrand et al., 2004) which is of high economical importance for the adjacent countries (Ryther, 1969; Urban and Tarazona, 1996; Food and Agricultural

\footnotetext{
* Corresponding author. Tel.: +49 47148312025.

E-mail address: monika.weiss@awi.de (M. Weiss).
}

Organization, 2006). The availability of resources is highly dependent on the global coupled ocean-atmosphere phenomenon El Niño Southern Oscillation (ENSO) (Lehodey et al., 2006). During El Niño various abiotic and biotic conditions change: i.e., temperature rises, salinity is reduced, sedimentation and turbidity increases in some regions, radiation increases due to clear oceanic water in others, predation and competition increase by invaders and food shortage occurs (Arntz et al., 1988). Those changing conditions during El Niño have some positive effects like immigration of commercially valuable tropical species (e.g. the shrimp Xiphopenaeus riveti) and an outbreak of some commercial exploited local species, such as the scallop Argopecten purpuratus (Arntz et al., 1988). However, the negative effects and damage caused by collapsing local populations of other important species, like the hairy crab, Cancer setosus, likely caused by the sudden and drastic temperature rise prevails by far in local artisanal fisheries (Arntz et al., 1988). Only few artisanal fishermen are able to take advantage of the immigration of tropical species during El Niño since they do not have the right fishing gears (O'Riordan, 1998).

Cancer setosus (Molina 1782; synonymous C. polyodon Poeppig $1836)$ ranges in its distribution from Guayaquil in Ecuador $\left(2^{\circ} 13^{\prime} \mathrm{S}\right.$, $\left.79^{\circ} 53^{\prime} \mathrm{W}\right)$ to the Peninsula of Taitao in Southern Chile $\left(46^{\circ} 00^{\prime} \mathrm{S}\right.$, $75^{\circ} 00^{\prime}$ W) (Garth and Stephenson, 1966; Fischer and Thatje, 2008) and its commercial value for the Chilean and Peruvian artisanal fishery increased during the last decades (Wolff and Soto, 1992; SERNAPESCA, 2006; Thatje et al., 2008). The early ontogeny, which in C. setosus 
consists of five planktotrophic zoeal stages (zoea I-V $=\mathrm{ZI}-\mathrm{V}$ ) and one megalopa before reaching the first crab stage (Quintana and Saelzer, 1986), is considered as the most delicate part within the life cycle of brachyuran and in particular cancrid crabs (Anger, 2001; Weiss et al., in press). A unique physiological plasticity to respond to latitudinal and seasonal changes in temperature, has been observed in early egg traits of $C$. setosus. Among the most conspicuous characteristics is a synchronization of a single egg batch release with seasonality at the species southernmost distribution boundary in central southern Chile, contrasted by multiple annual ovipositions in northern Chile (Antofagasta). In addition, a correlation of changes in egg energy contents and temperature was observed along latitude as well as in subsequent ovipositions in the same female (Fischer et al., 2009).

Temperature affects all levels of biological organization ranging from cellular to organismal level (Guderley and St-Pierre, 2002) and cause changes in the metabolic efficiency or fitness of an organism (Pörtner, 2001; Pörtner et al., 2005), which presumably is reflected in its elemental and biochemical composition (Dahlhoff, 2004). In this study we draw a picture of larval destiny during ENSO temperature oscillations to improve our knowledge of mechanisms of temperature adaptations in $C$. setosus larvae. We define the temperature window of C. setosus larvae for the Antofagasta region (northern Chile), and reveal the influences of temperature changes throughout ENSO on larval elemental composition and survival.

\section{Materials and methods}

\subsection{Sampling and maintenance of adults}

Ovigerous C. setosus (carapace width, CW 101 to $120 \mathrm{~mm}$ ) were caught between February and May 2007 by fishermen of the "Caleta Colosso" $\left(23^{\circ} 45^{\prime} \mathrm{S}, 70^{\circ} 27^{\prime} \mathrm{W}\right)$ by scuba diving and were immediately transferred to the laboratory of the Instituto de Investigaciones Oceanológicas of the Universidad de Antofagasta, Chile. Animals were maintained individually in flow-through seawater aquaria (12 1) at ambient temperature $\sim 16.0{ }^{\circ} \mathrm{C}$ and salinity 34 psu in a $12: 12$-h light/ dark cycle and fed ad libitum with living Perumytilus purpuratus.

\subsection{Experimental set-up}

Freshly hatched larvae were collected in filters receiving water from the overflow of the aquaria. Since most larvae hatched at night, samples were taken every morning. Filters were cleaned every evening to ensure daily larval age did not vary by more than $12 \mathrm{~h}$ (after Lovrich et al., 2003). Solely actively moving larvae were transferred to bowls with $16{ }^{\circ} \mathrm{C}$ filtered seawater and afterwards were allowed to acclimate to the experimental temperature in the corresponding temperature chamber for the experiments.

\subsubsection{Influence of temperature on larval survival and development}

Randomly selected larvae from one randomly selected female (A) were kept individually in glass bowls containing $100 \mathrm{ml}$ filtered seawater. For each experimental temperature $\left(12,16,20,22{ }^{\circ} \mathrm{C}\right)$ an initial number of 100 larvae was cultured in order to describe larval development and mortality. Water was changed daily; larvae were daily checked for moults or mortality and fed ad libitum with freshly hatched Artemia spp. nauplii. Survival rates and time of development for each instar was recorded. The mean duration of instars was calculated from all larvae that successfully passed through the moult into the subsequent stage.

\subsubsection{Influence of temperature on elemental composition}

Larvae from a randomly selected second female (B) were reared at 16,20 and $22{ }^{\circ} \mathrm{C} .12{ }^{\circ} \mathrm{C}$ as rearing temperature was excluded in this experiment, as the instar duration experiment showed extremely extended developmental times and exceptionally high mortality.
Larvae were kept in $500 \mathrm{ml}$ glass bowls (20 to 30 individuals/bowl) and provided with water and alimentation as described above. At each temperature an initial amount of 1000 larvae were randomly distributed into 35 glass bowls. At $20^{\circ} \mathrm{C}$, due to unforeseen technical problems, all larvae died, and a second set of experiments was conducted at $20^{\circ} \mathrm{C}$ with larvae of a third female (C).

For the analyses of dry weight $(W)$ and carbon $(C)$, hydrogen $(H)$ and nitrogen $(N)$ content throughout larval development, it was inevitable to pool specimens from the same hatch and developmental day in order to reach minimum required sample $W$. Each sample consisted of 30 individuals in the zoea I ( $\mathrm{Z} \mathrm{I)} \mathrm{on} \mathrm{the} \mathrm{day} \mathrm{of} \mathrm{hatching,}$ but less (see Table 1 ) in the following days and (larger) instars, in order to obtain minimum sample $W$ necessary for elemental analysis. Samples for elemental analyses were immediately taken after hatching and later every second day at $20^{\circ}$ and $22{ }^{\circ} \mathrm{C}$. At $16{ }^{\circ} \mathrm{C}$ samples were taken every fourth day due to the extended developmental time at lower temperatures. Three replicates of pooled larvae from the same hatch and developmental day were collected. Number of replicates was reduced, when too few larvae were available.

\subsection{Elemental analyses ( $\mathrm{CHN})$}

Carbon $(C)$, hydrogen $(H)$, nitrogen $(N)$ contents were determined following Anger and Dawirs (1982). In brief: larvae were gently rinsed in distilled water, blotted on filter paper, placed into pre-weighed tin cartridges and stored at $-80^{\circ} \mathrm{C}$. Afterwards samples were vacuumdried for $48 \mathrm{~h}$ in a Virtis Benchtop SLC freeze dryer at $-70^{\circ} \mathrm{C}$ and a pressure below 0.01 mbar before being stored in airtight boxes with silica gel. At the home institute samples were dried again, at $50{ }^{\circ} \mathrm{C}$ in a dry oven for $24 \mathrm{~h}$ and weighed to the nearest $0.1 \mu \mathrm{g}$ on a Sartorius M2P microbalance. CHN content was measured with a HEKAtech EURO EA 3000 CHNS-Analyzer using Acetanilid as a standard.

\subsection{Statistical analyses}

All data were tested with the Mahalanobis distances test (Mahalanobis, 1936) to exclude outliers from analysis. The effects of temperature and instar on instar duration and carbon gain per instar were analysed with a full interaction analysis of covariance (ANCOVA). Data were Box-Cox transformed (Sokal and Rohlf, 1981) to reach the best transformation to approach the normal distribution of residuals. An ANOVA was conducted to test for significant differences in the biochemical composition $(C, H, N)$ between freshly hatched larvae of 9 females including female B and $C$. To test whether slopes and intercepts of $C \%$ and $C: N$ with time are significantly different from zero, we conducted a slope analyses. A general additive model (Hastie and Tibshirani, 1990) including an ANOVA was used to describe larval mass $(\mu \mathrm{g} C)$ as a function of time ( $t$, days) and temperature ( $T$, Kelvin):

$C_{\mathrm{BC}}=a+b_{1} \times t+b_{2} \times f(T)+b_{3} \times t \times f(T) \quad[\mu g, d, K]$

where $C_{\mathrm{BC}}$ is the Box-Cox transformed larval mass (Sokal and Rohlf, 1981 ) and $f(T)$ a function that models the temperature effect according to a skewed normal distribution with mean $M_{\mathrm{T}}$, standard deviation $\mathrm{SD}_{\mathrm{T}}$ and skewing factor $\mathrm{SK}_{\mathrm{T}}$ following the method described in Weiss et al. (in press):

$$
\begin{aligned}
f(t)= & 1 /\left(\mathrm{SD}_{T} \times \sqrt{2 \pi}\right) \\
& \times e^{-0.5 \times\left(\left(\left(T-M_{T}\right)+\mathrm{SK}_{T} \times\left(T-M_{T}\right)\right) / \mathrm{SD}_{T}\right)^{2}} \text { for } T>=M_{T}
\end{aligned}
$$

$$
\begin{aligned}
f(t)= & 1 /\left(\mathrm{SD}_{T} \times \sqrt{2 \pi}\right) \\
& \times e^{-0.5 \times\left(\left(\left(T-M_{T}\right)-\mathrm{SK}_{T} \times\left(T-M_{T}\right)\right) / \mathrm{SD}_{T}\right)^{2}} \text { for } T<M_{T}
\end{aligned}
$$




\section{Results}

\subsection{Influence of temperature on larval survival and development}

Complete zoeal development occurred at $16^{\circ}$ and $20{ }^{\circ} \mathrm{C}$ only (Fig. 1). Most zoea $\mathrm{V}$ died during the moult to the megalopa stage. At $12^{\circ}$ and $22{ }^{\circ} \mathrm{C}$ development proceeded until zoea IV. At all temperatures mortality was high especially during ecdysis and only few larvae reached the higher instars (zoea IV/V). At $12{ }^{\circ} \mathrm{C}$ mortality was exceptionally high in the zoea I instar. $85 \%$ of the larvae died within the first five days after hatching. Development up to zoea IV took 84 days and another 27 days until all remaining larvae died. At $16{ }^{\circ} \mathrm{C}$ mortality in the zoea I stage was lower (33\% within 5 days) and the whole zoeal development took 84 days until the last zoea $\mathrm{V}$ died. At $20{ }^{\circ} \mathrm{C}$ mortality was comparatively low within zoea I (22\% within
5 days) and total development took 36 days. Zoeal development at $22{ }^{\circ} \mathrm{C}$ was fast; the last larvae died after 22 days in a zoea IV instar. Mortality in zoea I was on an intermediate level.

The mean instar duration was significantly shorter at higher temperatures $(p<0.0001, F=1230.814, \mathrm{DF}=3)$, this temperature effect is instar specific $(p<0.0001, F=377.351, \mathrm{DF}=2)$ and the interaction term between temperature and instar also had a significant influence, indicating that slopes of instar duration depending on temperature are not parallel.

\subsection{Influence of temperature on elemental composition}

All changes in $W$ and $C H N$ during the course of larval development are shown in Table 1. As an example the initial larval $W$ for zoea I at $20{ }^{\circ} \mathrm{C}$ was $13.62 \pm 0.34 \mu \mathrm{g}$, while a zoea $\mathrm{V}$ at $20^{\circ} \mathrm{C}$ had a maximal dry

Table 1

Cancer setosus.

\begin{tabular}{|c|c|c|c|c|c|c|c|c|c|c|c|c|c|}
\hline \multirow[t]{2}{*}{$T\left[{ }^{\circ} \mathrm{C}\right]$} & \multirow[t]{2}{*}{ Instar } & \multirow[t]{2}{*}{ Ind/sample } & \multirow[t]{2}{*}{ Day } & \multicolumn{2}{|l|}{$W[\mu \mathrm{g}]$} & \multicolumn{2}{|l|}{$N[\mu \mathrm{g}]$} & \multicolumn{2}{|l|}{$C[\mu \mathrm{g}]$} & \multicolumn{2}{|l|}{$H[\mu \mathrm{g}]$} & \multicolumn{2}{|l|}{$C / N$} \\
\hline & & & & Mean & $\pm \mathrm{SD}$ & Mean & $\pm \mathrm{SD}$ & Mean & $\pm \mathrm{SD}$ & Mean & $\pm \mathrm{SD}$ & Mean & $\pm \mathrm{SD}$ \\
\hline \multirow[t]{14}{*}{$\overline{16}$} & ZI & 30 & 0 & 10.624 & 0.390 & 0.805 & 0.010 & 3.364 & 0.045 & 0.436 & 0.009 & 4.177 & 0.035 \\
\hline & ZI & 25 & 4 & 20.753 & 0.906 & 1.310 & 0.087 & 6.248 & 0.367 & 0.820 & 0.051 & 4.771 & 0.040 \\
\hline & ZI & 20 & 8 & 27.307 & 0.698 & 2.027 & 0.024 & 9.679 & 0.118 & 1.291 & 0.023 & 4.775 & 0.002 \\
\hline & ZI & 15 & 12 & 24.136 & 3.675 & 1.679 & 0.093 & 7.212 & 0.195 & 0.899 & 0.027 & 4.308 & 0.344 \\
\hline & ZII & 15 & 0 & 36.658 & 1.496 & 2.360 & 0.071 & 11.258 & 0.434 & 1.479 & 0.055 & 4.769 & 0.042 \\
\hline & ZII & 15 & 4 & 54.902 & 0.938 & 3.751 & 0.091 & 18.400 & 0.493 & 2.474 & 0.084 & 4.906 & 0.029 \\
\hline & ZII & 10 & 8 & 61.850 & 2.203 & 4.703 & 0.242 & 21.588 & 1.084 & 2.863 & 0.159 & 4.590 & 0.013 \\
\hline & ZII & 12 & 12 & 56.700 & 4.268 & 4.251 & 0.396 & 17.553 & 1.730 & 2.322 & 0.245 & 4.128 & 0.023 \\
\hline & ZIII & 10 & 0 & 63.537 & 3.703 & 4.838 & 0.135 & 21.257 & 1.052 & 2.862 & 0.139 & 4.392 & 0.097 \\
\hline & ZIII & 10 & 4 & 91.073 & 4.707 & 6.312 & 0.416 & 28.434 & 2.325 & 3.913 & 0.386 & 4.502 & 0.109 \\
\hline & ZIII & 10 & 8 & 94.787 & 3.689 & 6.903 & 0.308 & 29.535 & 1.488 & 4.082 & 0.224 & 4.278 & 0.034 \\
\hline & ZIII & 5 & 12 & 83.780 & 5.082 & 6.044 & 0.448 & 23.967 & 2.139 & 3.139 & 0.320 & 3.963 & 0.062 \\
\hline & ZIII & 5 & 16 & 73.940 & 1.782 & 5.595 & 0.011 & 22.021 & 0.089 & 2.819 & 0.006 & 3.936 & 0.008 \\
\hline & ZIV & 1 & 0 & 96.000 & & 4.908 & & 21.645 & & 2.210 & & 4.410 & \\
\hline \multirow[t]{23}{*}{20} & ZI & 30 & 0 & 13.618 & 0.341 & 0.806 & 0.019 & 3.688 & 0.079 & 0.445 & 0.009 & 4.576 & 0.011 \\
\hline & ZI & 25 & 2 & 24.693 & 0.340 & 1.279 & 0.003 & 6.912 & 0.015 & 0.897 & 0.019 & 5.404 & 0.023 \\
\hline & ZI & 20 & 4 & 26.100 & 0.786 & 1.475 & 0.058 & 7.542 & 0.297 & 0.971 & 0.038 & 5.112 & 0.043 \\
\hline & ZI & 15 & 6 & 30.689 & 0.847 & 1.941 & 0.111 & 9.970 & 0.476 & 1.284 & 0.070 & 5.139 & 0.053 \\
\hline & ZI & 15 & 8 & 29.200 & 0.406 & 1.784 & 0.044 & 9.050 & 0.217 & 1.132 & 0.031 & 5.074 & 0.025 \\
\hline & ZII & 15 & 0 & 37.733 & 1.453 & 2.223 & 0.067 & 11.755 & 0.401 & 1.552 & 0.045 & 5.293 & 0.279 \\
\hline & ZII & 10 & 2 & 58.022 & 2.076 & 3.460 & 0.168 & 18.475 & 1.052 & 2.511 & 0.156 & 5.339 & 0.082 \\
\hline & ZII & 10 & 4 & 100.400 & 1.323 & 6.624 & 0.142 & 34.702 & 0.965 & 4.842 & 0.159 & 5.239 & 0.041 \\
\hline & ZII & 10 & 6 & 63.000 & 2.600 & 4.330 & 0.214 & 21.119 & 1.322 & 2.810 & 0.201 & 4.875 & 0.066 \\
\hline & ZIII & 5 & 0 & 75.067 & 2.914 & 4.993 & 0.161 & 23.819 & 0.611 & 3.288 & 0.126 & 4.771 & 0.064 \\
\hline & ZIII & 5 & 2 & 111.333 & 2.532 & 6.869 & 0.203 & 34.663 & 1.116 & 4.555 & 0.156 & 5.046 & 0.080 \\
\hline & ZIII & 5 & 4 & 121.733 & 3.478 & 8.156 & 0.254 & 39.838 & 1.379 & 5.271 & 0.184 & 4.885 & 0.061 \\
\hline & ZIII & 5 & 6 & 124.800 & 2.771 & 8.795 & 0.203 & 41.397 & 1.054 & 5.516 & 0.183 & 4.707 & 0.012 \\
\hline & ZIV & 5 & 0 & 147.133 & 7.100 & 9.969 & 0.325 & 44.733 & 1.391 & 6.045 & 0.222 & 4.488 & 0.052 \\
\hline & ZIV & 5 & 2 & 197.933 & 17.900 & 11.831 & 1.408 & 55.763 & 6.902 & 7.656 & 1.054 & 4.712 & 0.046 \\
\hline & ZIV & 5 & 4 & 206.733 & 14.607 & 13.737 & 1.559 & 63.686 & 7.673 & 8.842 & 1.166 & 4.634 & 0.039 \\
\hline & ZIV & 3 & 6 & 226.556 & 17.513 & 15.753 & 1.466 & 70.853 & 7.335 & 9.526 & 1.078 & 4.495 & 0.057 \\
\hline & ZIV & 3 & 8 & 263.667 & 20.809 & 20.758 & 2.239 & 93.527 & 10.309 & 13.166 & 1.417 & 4.507 & 0.146 \\
\hline & ZV & 3 & 0 & 307.222 & 28.578 & 21.302 & 1.467 & 94.240 & 6.722 & 13.390 & 1.038 & 4.423 & 0.026 \\
\hline & ZV & 3 & 2 & 384.667 & 27.966 & 26.668 & 2.059 & 124.221 & 9.925 & 17.886 & 1.489 & 4.657 & 0.013 \\
\hline & ZV & 3 & 4 & 400.444 & 50.536 & 29.906 & 4.006 & 132.893 & 21.163 & 19.382 & 2.978 & 4.434 & 0.124 \\
\hline & ZV & 3 & 6 & 360.222 & 174.243 & 27.299 & 13.165 & 120.631 & 57.603 & 17.670 & 8.892 & 4.431 & 0.045 \\
\hline & ZV & 3 & 8 & 168.667 & & 13.793 & & 61.377 & & 8.284 & & 4.450 & \\
\hline \multirow[t]{17}{*}{22} & ZI & 30 & 0 & 10.624 & 0.390 & 0.805 & 0.010 & 3.364 & 0.045 & 0.436 & 0.009 & 4.177 & 0.035 \\
\hline & ZI & 25 & 2 & 20.693 & 1.054 & 1.331 & 0.049 & 6.075 & 0.299 & 0.786 & 0.044 & 4.565 & 0.073 \\
\hline & ZI & 20 & 4 & 25.083 & 1.382 & 1.896 & 0.144 & 8.296 & 0.598 & 1.068 & 0.080 & 4.377 & 0.045 \\
\hline & ZI & 15 & 6 & 23.711 & 0.948 & 1.830 & 0.096 & 7.506 & 0.469 & 0.925 & 0.059 & 4.100 & 0.067 \\
\hline & ZII & 15 & 0 & 27.178 & 0.454 & 2.124 & 0.053 & 8.512 & 0.284 & 1.081 & 0.043 & 4.008 & 0.109 \\
\hline & ZII & 10 & 2 & 51.511 & 1.699 & 3.522 & 0.190 & 16.304 & 0.683 & 2.178 & 0.097 & 4.631 & 0.062 \\
\hline & ZII & 10 & 4 & 58.633 & 4.801 & 4.816 & 0.628 & 19.827 & 2337 & 2.582 & 0.339 & 4.124 & 0.141 \\
\hline & ZII & 10 & 6 & 52.500 & 2.458 & 3.520 & 0.267 & 17.160 & 1433 & 2.391 & 0.194 & 4.873 & 0.038 \\
\hline & ZIII & 10 & 0 & 63.833 & 2.230 & 4.066 & 0.126 & 19.503 & 0.568 & 2.730 & 0.092 & 4.797 & 0.066 \\
\hline & ZIII & 5 & 2 & 93.867 & 2.120 & 5.698 & 0.145 & 29.590 & 0.689 & 4.044 & 0.104 & 5.194 & 0.026 \\
\hline & ZIII & 5 & 4 & 107.333 & 3.911 & 7.186 & 0.354 & 35.599 & 2.011 & 4.931 & 0.269 & 4.953 & 0.070 \\
\hline & ZIII & 5 & 6 & 117.933 & 3.754 & 8.324 & 0.377 & 40.611 & 1.735 & 5.624 & 0.277 & 4.879 & 0.017 \\
\hline & ZIV & 5 & 0 & 134.867 & 8.011 & 8.415 & 0.230 & 39.200 & 1.147 & 5.458 & 0.124 & 4.661 & 0.201 \\
\hline & ZIV & 5 & 2 & 156.000 & 6.409 & 9.894 & 0.750 & 46.890 & 4.064 & 6.650 & 0.650 & 4.256 & 0.241 \\
\hline & ZIV & 5 & 4 & 196.400 & 15.565 & 13.565 & 1.456 & 64.325 & 6.670 & 9.226 & 1.010 & 4.743 & 0.080 \\
\hline & ZIV & $3 / 3 / 2$ & 6 & 161.667 & 26.359 & 10.859 & 2.316 & 51.237 & 12.776 & 6.921 & 1.623 & 4.697 & 0.181 \\
\hline & ZIV & $5 / 1$ & 8 & 121.600 & 31.961 & 6.865 & 4.233 & 32.661 & 16.939 & 4.230 & 2.930 & 4.936 & 0.576 \\
\hline
\end{tabular}

Changes in dry weight $(W)$, carbon $(C)$, nitrogen $(N)$ and $C: N$ ratio during time days after hatch $( \pm \operatorname{SD})$ at four temperatures. 


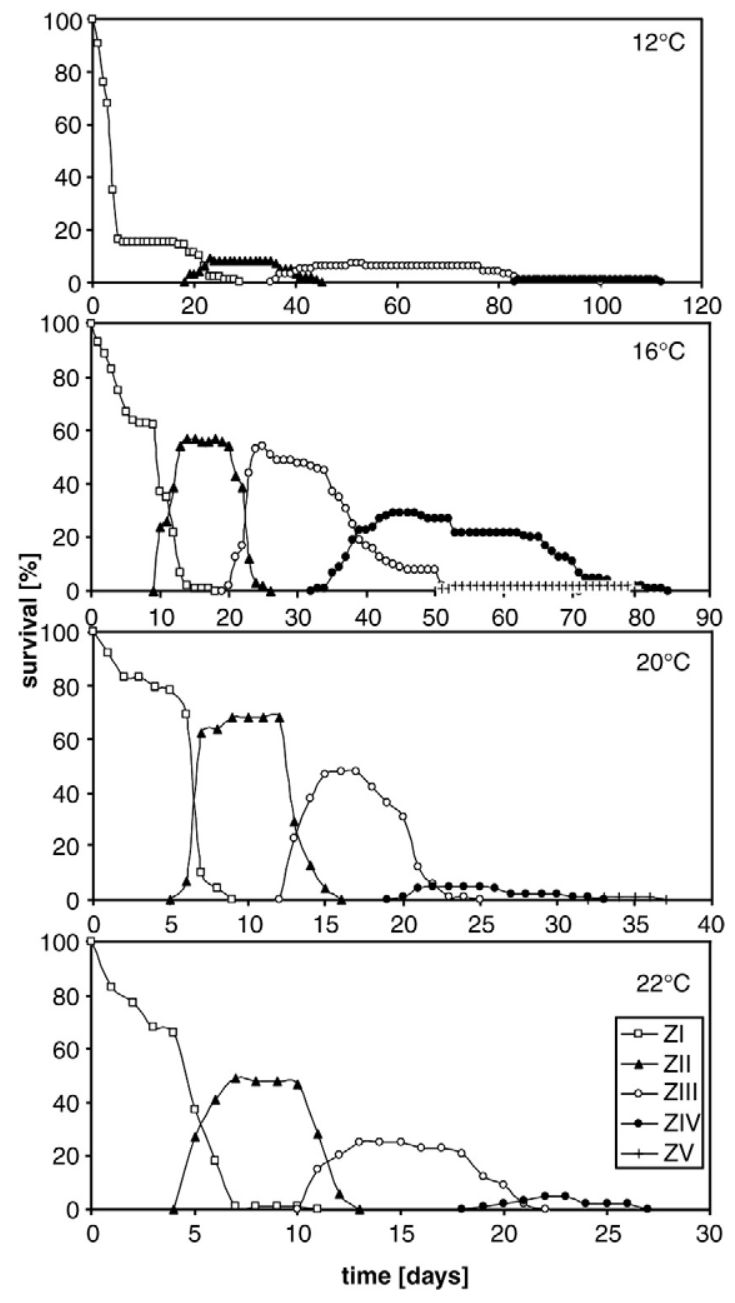

Fig. 1. Cancer setosus. Instar duration and larval survival at four temperatures (12, 16, 20 and $22{ }^{\circ} \mathrm{C}$ ). ZI-ZV are zoeal instars I-V.

weight of $400.44 \pm 50.54 \mu \mathrm{g}$, which means a growth rate of $2940 \%$. The growth factor $F_{\mathrm{G}}$ (maximum carbon content of last-stage zoea divided by minimum in freshly hatched zoea I) is 36.6. A comparison of the CHN content of freshly hatched larvae of 9 different females revealed that larvae of female $\mathrm{B}$ and $\mathrm{C}$ have intermediate $\mathrm{CHN}$ values that do not differ significantly from each other.

At $20{ }^{\circ} \mathrm{C}$ the slope of the relative carbon content (\% W) (Fig. 2) shows a significant positive tendency, while the slopes of $16^{\circ}$ and $22{ }^{\circ} \mathrm{C}$ do not show significant trends. At $22{ }^{\circ} \mathrm{C}$ the slope increases within the first three zoeal instars and decreases in zoea IV. The C:N ratio generally increases during the postmoult, reaches a maximum in the intermoult and has a decreasing tendency in the premoult phase (Fig. 2). The slopes of the $C: N$ ratio over the complete recorded larval development were significantly different from zero $(p<0.0001)$. Slopes show a decrease at $16^{\circ}$ and $20^{\circ} \mathrm{C}$, and increases at $22^{\circ} \mathrm{C}$.

The variation in growth of the single instars is shown in Fig. 3, here the carbon gain in \% of initial carbon per instar is shown separately (given as percentage of the initial value measured for each instar)

\%gain $=\frac{\left(C \mu g \times \text { ind }_{\text {final }}^{-1}-C \mu g \times \text { ind }_{\text {initial }}^{-1}\right)}{\left(C \mu g \times \text { ind }_{\text {initial }}^{-1} \times 100\right)}$.

The results of the ANCOVA showed that temperature $(p<0.0001$, $F=16883.666, \mathrm{DF}=2)$ and instar $(p<0.0001, F=71.571, \mathrm{DF}=2)$, as
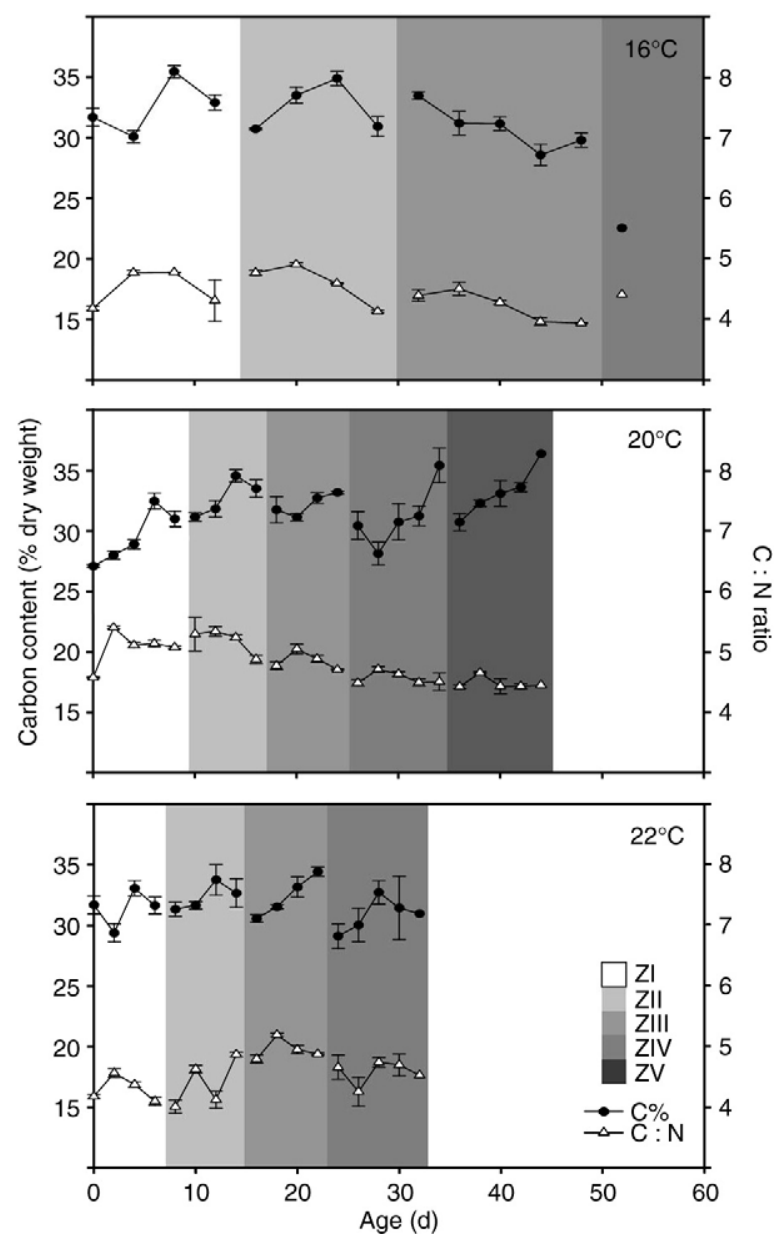

Fig. 2. Cancer setosus. Changes during larval development in the carbon content (\% of body mass, $\mathrm{W})$ and in the carbon: nitrogen $(C: N)$ weight ratio of larvae reared at three temperatures.

well as the interaction term $(p<0.0001, F=10634.729, \mathrm{DF}=4)$ have a significant influence on the instar growth rates. The significantly highest growth rates occur in the zoea I at all three tested temperatures with the highest increment at $20^{\circ} \mathrm{C}$, followed by an intermediate growth at $22^{\circ} \mathrm{C}$ and a slightly lower rate at $16{ }^{\circ} \mathrm{C}$. In the zoea II and zoea III instar the highest growth rates occur at $22{ }^{\circ} \mathrm{C}$, followed by an intermediate

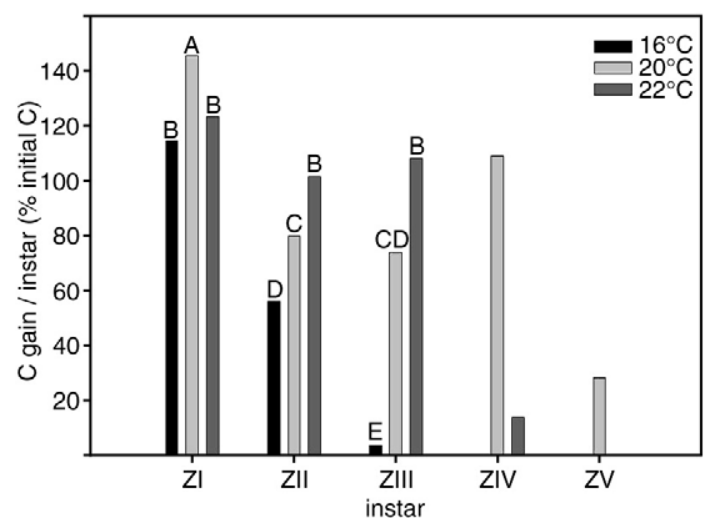

Fig. 3. Cancer setosus. Increment in carbon (carbon gain in \% of initial carbon per instar) in each instar of larvae reared at three temperatures. Bars marked with different letters are significantly different. 
increment at $20^{\circ} \mathrm{C}$ and the smallest increment at $16{ }^{\circ} \mathrm{C}$. Data for zoea IV and $\mathrm{V}$ were not included in the statistical analyzes due to missing values (zoea IV, $16{ }^{\circ} \mathrm{C}$; zoea V $16^{\circ}$ and $22{ }^{\circ} \mathrm{C}$ ), caused by death of all larvae. Nonetheless data are presented in Fig. 3 to show the consecutive pattern. In the zoea IV instar larvae reared at $20{ }^{\circ} \mathrm{C}$ show a clearly higher increment than at $22^{\circ} \mathrm{C}$. The growth rate of larvae reared at $20^{\circ} \mathrm{C}$ was lowest in zoea $\mathrm{V}$. It has to be mentioned that we did not include the last sampling day in the graph, as at day 8 of the zoea $V$ only few larvae were alive for sampling and we could not take any replicates.

Larval body mass ( $C$ in $\mu \mathrm{g} /$ ind) is predicted from day $(t)$ and temperature $\left(T^{\circ} \mathrm{C}\right)$ by the model

$$
\begin{aligned}
\log _{e}(C)= & -9.575-10.927 \times t+926.034 \times f(T) \\
& +899.829 \times t \times f(T)
\end{aligned}
$$

$N=151, F=637.9388, R^{2}=0.93, p<0.001$ for the whole model and each term with

$$
\begin{aligned}
f(T)= & 0.012234462 \\
& \times e^{\left.-0.5 \times(((T-21.58)+(T-21.58)+0.5 \times(T-21.58)) \div 32.608)^{2}\right)} \\
& \quad \text { for } T>=21.58^{\circ} \mathrm{C} \\
f(T)= & 0.012234462 \\
& \times e^{-0.5 \times\left((((T-21.58)+(T-21.58)-0.5 \times(T-21.58)) \div 32.608)^{2}\right)} \\
& \quad \text { for } T<21.58^{\circ} \mathrm{C}
\end{aligned}
$$

The Box-Cox test found $\log _{\mathrm{e}}$ to be the most appropriate transformation.

$C_{\mathrm{BC}}=\log _{e}(C)$

Note that this model (Fig. 4) predicts a larval mass for just any combination of time and temperature; whereas our experiments indicate that the "time $\times$ temperature" space where larvae do exist is limited (see Discussion). Outside these margins larval development beyond zoea I is not possible $\left(24^{\circ} \mathrm{C}\right.$, preliminary experiments), or mortality is exceptionally high and zoeal development theoretically took several months and could not be completed $\left(12{ }^{\circ} \mathrm{C}\right)$. The residual plot (Fig. 5) indicates that the model fit the data well, but slightly overestimates body mass of freshly hatched larvae. In late premoult

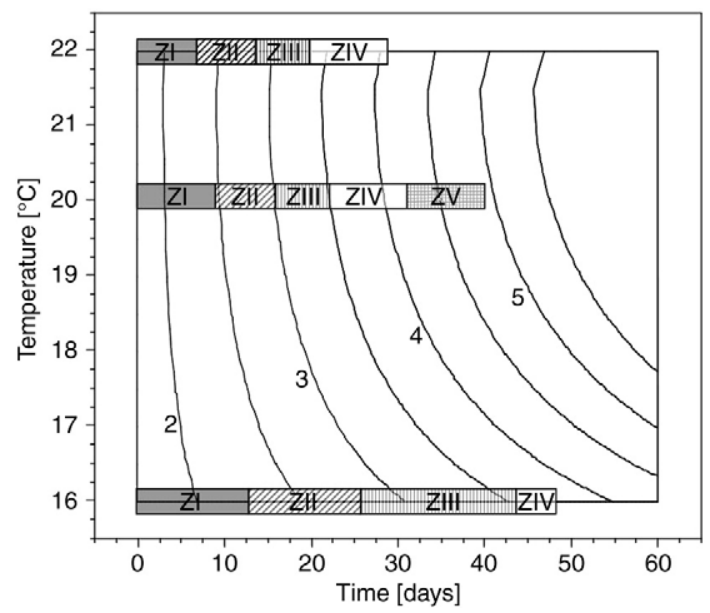

Fig. 4. Model of body mass increase $(C)$ throughout the larval development of the edible crab Cancer setosus. Equation for the model is: $\log _{e}(C)=-9.575-10.927 \times$ $t \times 926.034 \times f(T)+899.829 \times t \times f(T) ; N=151, F=637.9388, R^{2}=0.93, p<0.001 ; T$ represents the temperature in ${ }^{\circ} \mathrm{C}$ and $t$ the time in days. Isolines represent carbon content in $\mathrm{ln}$ $\mu$ g. ZI-ZV are the larval instars.

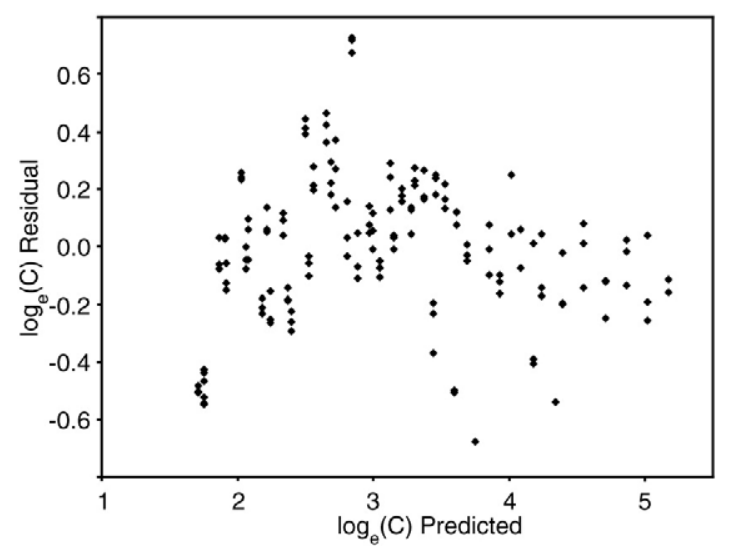

Fig. 5. Residual by predicted plot from the model predicting larval body mass in Cancer setosus: plot of regression residuals versus predicted values.

stages of higher instars, changes in carbon values were generally lower than predicted by the model (compare Figs. 4 and 5).

\section{Discussion}

In the present study, complete zoeal development from hatching to zoea $\mathrm{V}$ was only successful within a narrow temperature range of approximately $16^{\circ}$ and $20{ }^{\circ} \mathrm{C}$ (Fig. 1). The general increase of the relative carbon content (Fig. 2) combined with an decrease of the $C: N$ ratio at $20^{\circ} \mathrm{C}$, points at lipid storage and likely construction of muscle proteins (Torres and Childress, 1985). The growth of larvae measured as the increment in carbon per instar (Fig. 3) is relatively high at $20^{\circ} \mathrm{C}$ during each instar, but significantly the highest in the zoea I. Those findings indicate $20{ }^{\circ} \mathrm{C}$ as the optimal temperature for larvae of the Antofagasta $C$. setosus population during summer and early fall months. The temperature range of $16^{\circ}$ to $20^{\circ} \mathrm{C}$ corresponds with the normal annual temperature fluctuation in the Antofagasta region (SHOA, 2008). At temperatures below or above the optimal range, development could not be completed, suggesting that lower and upper Pejus temperatures for successful zoeal development (sensu Pörtner, 2001) are $12{ }^{\circ} \mathrm{C}$ and $22{ }^{\circ} \mathrm{C}$, respectively. Beyond Pejus temperatures survival is likely restricted due to a mismatch between oxygen supply and demand (Pörtner, 2001; Pörtner et al., 2005)).

The growth problems (illustrated by incomplete zoeal development) of larvae that occur at $16^{\circ}$ and $22^{\circ} \mathrm{C}$ are also reflected in their elemental composition. At $16{ }^{\circ} \mathrm{C}$ the overall relative carbon content decreases slightly and the $C: N$ increases (Fig. 2), because the absolute nitrogen content stays constant (Table 1 ). This indicates a metabolism that is mainly based on carbon, which refers to a higher overall lipid than protein metabolism. The general decrease in $C$ (\% W, Fig. 2) indicates that $16{ }^{\circ} \mathrm{C}$ is below the temperature optimum for $C$. setosus larvae. Similar patterns were found in Carcinus maenas larvae suffering from starvation (Dawirs, 1986), temperature (Dawirs et al., 1986) and osmotic stress (Torres et al., 2002). Here, carbon is metabolized at higher rates than nitrogen, which indicates that unfavourable conditions have comparable effects on the metabolism of larvae (Anger, 2001; Heilmayer et al., 2008). At $22^{\circ} \mathrm{C}$, the generally constant overall relative carbon content and the increasing $C: N$ ratio points to protein degradation due to high metabolism, which is also described for larvae after long periods of food deprivation (Anger, 2001) and likely the result of a mismatch of energy supply and energy demand. These results basically reflect the hypothesis of the point of reserve saturation (PRS) and the corresponding $D_{0}$ threshold (Anger, 1987). The unfavourable nutritional conditions reflected by the elemental composition are comparable with conditions of starvation, at least in the last completed instar (ZIII at $16{ }^{\circ} \mathrm{C}$, ZIV hat $22^{\circ} \mathrm{C}$ ). This 
would indicate that the respective instar development had been completed despite starvation, meaning transgression of the $D_{0}$ threshold and the PRS.

Short term temporal changes in the relative carbon content $(\% W)$ show the typical cyclic pattern (Fig. 2) (Anger, 1988; Anger, 2001) within individual moult cycles with decreased carbon values after ecdysis due to rapid water and mineral uptake during the initial phase of a moult cycle. One exception occurs after ecdysis from zoea II to zoea III where the carbon content is higher after moulting. The $C: N$ (carbon: nitrogen) ratio, is an index of the lipid: protein ratio (e.g. Anger and Harms, 1990; Minagawa et al., 1993). Both, lipids and proteins serve as the most important energy reserves in decapod crustaceans (Cockcroft, 1997). The $C: N$ values also shows a typical short term pattern described for several brachyurans, with low values after moulting and an increase on the following days (Dawirs et al., 1986; Anger, 1988; Minagawa et al., 1993) and a slight decrease towards moulting. This indicates a higher lipid metabolism shortly after ecdysis, followed by an increasing protein accumulation.

Growth of larvae, measured as carbon increment per instar (Fig. 3) at $16{ }^{\circ} \mathrm{C}$ clearly declines with instar, indicating a temperature limitation of growth. At $20{ }^{\circ} \mathrm{C}$ increment is high in each instar, but decreases in the zoea $\mathrm{V}$. This instar is characterized by growth in the first four days and a following decrease in absolute carbon values (Table 1), giving evidence that the cue for metamorphosis to the megalopa stage is missing. It is known that larvae are able to postpone their metamorphosis to the megalopa stage if the cue for the suitable habitat cannot be detected (Krimsky and Epifanio, 2008), but the enduring lack of those cues cause stress and the depletion of resources. We conducted an additional preliminary experiment following Forward et al. (2001) to detect potential chemical or physical cues for metamorphosis with exudates of adults, rubble, macroalgae, shells and mesh. None of the larvae moulted successfully to the megalopa stage. Another reason that moulting to the megalopa fails might be that Artemia spp. nauplii are an insufficient food source for higher zoeal instars, although this is unlikely as growth was successful during the first days and larvae are known to stop food uptake shortly before ecdysis (Al-Mohanna and Nott, 1989). Successful metamorphosis is a well known problem in cancrid larva to date and requires much closer investigation (Quintana and Saelzer, 1986; Anger, 2001; Weiss et al., in press).

The cumulative growth during larval development of $2940 \%$ with a growth factor $\left(F_{\mathrm{G}}\right)$ of 36.6 is one of the highest recorded for decapod crustacean species (Anger, 1995). It is interesting to observe that the congener Cancer pagurus from the North Sea has a cumulative larval growth rate of $876 \%$ and a growth factor of 9.2 only (Anger, 1995; Weiss et al., in press). Instar dependent increment is highest at $20^{\circ} \mathrm{C}$ in the zoeal I instar, but in zoea II and III maximal growth can be detected at $22{ }^{\circ} \mathrm{C}$. In contrast in the zoea IV instar the increment is clearly higher at $20{ }^{\circ} \mathrm{C}$ than at $22{ }^{\circ} \mathrm{C}$. According to these changes in the maximum growth in successive instars, $C$. setosus larvae show an ontogenetic shift in the instar specific temperature optimum (Anger, 2001). While in the zoea I and II instar growth is visible at all tested temperatures (Fig. 3), a steep drop in growth occurs in the zoea III at $16{ }^{\circ} \mathrm{C}$ and in the zoea IV at $22{ }^{\circ} \mathrm{C}$. These findings indicate that lower instars are more temperature tolerant. Shifts in the temperature preference of larvae can be due to seasonal increase in water temperature during larval development as described for Hyas araneus larvae by Anger (2001). Since C. setosus in northern Chile is eggbearing all year round (Fischer and Thatje, 2008), it is unlikely that this shift in temperature optimum is due to seasonal acclimation. It is known that larval crabs migrate vertically and that these movements change during ontogeny (Shanks, 1986; Hobbs and Botsford, 1992), but no consistent pattern within a genus could be found. Therefore, different temperature optima during ontogeny might reflect the preference of water masses with different temperatures dependent on the instar.
The positive temperature effect described for the time of development of larvae is also reflected in the growth model (Fig. 4). Beyond Pejus temperatures a reduced feeding activity in the cold and an unbalanced equilibrium between ingestion rates and maintenance costs at warm temperatures lead to reduced growth rates and cause the death of larvae. Herein, the most vulnerable part of the larval moult cycle is the transition from one instar to the next (also obvious in survival rates, see Fig. 1) (Anger, 2001). The residual plot (Fig. 5) shows a general good fit of the model (i.e., randomly distribution of residuals) and slightly lower carbon values in higher instars (zoea V) than predicted by the model (Fig. 4), which might be due to problems during metamorphosis to the megalopa stage.

In comparison with findings of Quintana and Saelzer (1986), who reared $C$. setosus larvae of a population from Coliumo Bay (Concepción, central Chile) under natural temperature conditions (13.5$14.6^{\circ} \mathrm{C}$ ), larvae from the Antofagasta region have a 1.5 times extended zoeal development at $16{ }^{\circ} \mathrm{C}$ (Fig. 1) and show higher survival rates, while larvae from Concepción are capable to develop through all zoeal instars at lower temperatures. These findings indicate a better cold adaptation of larvae originating from a southern population (see also Fischer and Thatje, 2008; Fischer et al., 2009). This adaptive variation in growth has been described for several ectotherms like Pisces (Yamahira and Conover, 2002), Polychaeta (Levinton, 1983), Bivalvia (Heilmayer et al., 2004) and Crustacea (Lonsdale and Levinton, 1985). Additionally those findings show that not only egg-size, reproductive output per egg batch (Brante et al., 2003) and oviposition (Fischer and Thatje, 2008) but also larval growth follows a latitudinal cline. This indicates that the species temperature tolerance window is much wider than the window of one single population, and this knowledge is important for a successful adaptive fisheries managing during and post-El Niño. We have to emphasize that conclusions made in this study are based on larvae of three different females from the same location. Due to the knowledge of dispersal of planktonic larvae it is realistic that larval answers to similar requirements are similar within a wide distributional range. We used larvae with an intermediate $C H N$ and $W$ and therefore we state that our results can be considered as representative for the whole population.

\section{Conclusion}

The optimum temperature for larval development of $C$. setosus from the Antofagasta population lies between $16^{\circ}$ and $20{ }^{\circ} \mathrm{C}$. Higher and lower temperatures cause changes in the elemental composition, which reflects a lower metabolic efficiency. A narrow temperature tolerance window throughout early ontogeny is surprising in a species that faces strong temperature oscillations beyond its upper thermal tolerance limit during conditions of El Niño. Future experiments should reveal if the temperature optimum is genetically defined or if the temperature experienced at embryonic development is crucial for temperature preference in later life.

\section{Acknowledgements}

We would like to thank Marcelo Oliva (Universidad de Antofagasta, Chile) for providing workspace in his laboratory and Aldo Pacheco for help with larval culture maintenance. This study is conducted in the frame of the EU-FP6-INCO project CENSOR (Climate variability and El Niño Southern Oscillation: Implications for natural coastal resources and management) (Contract no. 511071), and was further supported by the Marine Biodiversity and Ecosystem Functioning Network of Excellence MarBEF (Contract no. GOCE-CT-2003-505446). The German Academic Exchange Service (DAAD) supported MW with a travel grant to Chile (contract no. $415 \mathrm{D} / 07 / 47120$ ). This study is CENSOR publication No. 0374. [SS] 


\section{References}

Al-Mohanna, S., Nott, J., 1989. Functional cytology of the hepatopancreas of Penaeus semisulcatus (Crustacea, Decapoda) during the moult cycle. Mar. Biol. 101 (4), 535-544.

Anger, K., 1987. The $D_{\mathrm{o}}$ threshold: a critical point in the larval development of decapod crustaceans. J. Exp. Mar. Biol. Ecol. 108 (1), 15-30.

Anger, K., 1988. Growth and elemental composition (C, N, H) in Inachus dorsettensis (Decapoda: Majidae) larvae reared in the laboratory. Mar. Biol. 99 (2), 255-260.

Anger, K., 1995. The conquest of freshwater and land by marine crabs: adaptations in life-history patterns in larval bioenergetics. J. Exp. Mar. Biol. Ecol. 193 (1-2), $119-145$.

Anger, K., 2001. The biology of decapod crustacean larvae. In: Crustacean Issues, vol. 14. A.A. Balkema Publishers, Lisse. 420pp.

Anger, K., Dawirs, R.R., 1982. Elemental composition (C, N, H) and energy in growing and starving larvae of Hyas araneus (Decapoda, Majidae). Fish. Bull. 80, 419-433.

Anger, K., Harms, J., 1990. Elemental (CHN) and proximate biochemical composition of decapod crustacean larvae. Comp. Biochem. Physiol. 97b (1), 69-80.

Arntz, W.E., Valdivia, E., Zeballos, J., 1988. Impact of El Niño 1982-83 on the commercially exploited invertebrates (mariscos) of the Peruvian shore. Meeresforschung/Rep. Mar. Res. 32 (1), 3-22.

Bennett, D.B., 1995. Factors in the life history of the edible crab (Cancer pagurus L.) that influence modelling and management. In: Aiken, D.E., Waddy, S.L., Conan, G.Y. (Eds.), ICES marine science symposia. InIces, Copenhagen, pp. 89-98.

Bertrand, A., Segura, M., Gutierrez, M., Vasquez, L., 2004. From small-scale habitat loopholes to decadal cycles: a habitat-based hypothesis explaining fluctuation in pelagic fish populations off Peru. Fish Fish. 5 (4), 296-316.

Brante, A., Fernandez, M., Eckerle, L., Mark, F., Pörtner, H.-O., 2003. Reproductive investment in the crab Cancer setosus along a latitudinal cline: egg production, embryo losses and embryo ventilation. Mar. Ecol. Prog. Ser. 251, 221-232.

Cockcroft, A.C., 1997. Biochemical composition as a growth predictor in male west-coast rock lobster (Jasus lalandii). Mar. Fresh. Res. 48 (8), 845-856.

Dahlhoff, E.P., 2004. Biochemical indicators of stress and metabolism: applications for marine ecological studies. Annu. Rev. Physiol. 66, 183-207.

Dawirs, R.R., 1986. Influence of limited food supply on growth and elemental composition ( $\mathrm{C}, \mathrm{N}, \mathrm{H}$ ) of Carcinus maenas (Decapoda) larvae, reared in the laboratory. Mar. Ecol. Prog. Ser. 31 (3), 301-308.

Dawirs, R.R., Pueschel, C., Schorn, F., 1986. Temperature and growth in Carcinus maenas L. (Decapoda: Portunidae) larvae reared in the laboratory from hatching through metamorphosis. J. Exp. Mar. Biol. Ecol. 100 (1-3), 47-74.

Eaton, D.R., Brown, J., Addison, J.T., Milligan, S.P., Fernand, L.J., 2003. Edible crab (Cancer pagurus) larvae surveys off the east coast of England: implications for stock structure. Fish. Res. 65, 191-199.

Fischer, S., Thatje, S., 2008. Temperature-induced oviposition in the brachyuran crab Cancer setosus along a latitudinal cline: aquaria experiments and analysis of field-data. J. Exp. Mar. Biol. Ecol. 357 (2), 157-164.

Fischer, S., Thatje, S., Brey, T., 2009. Early egg-traits in Cancer setosus (Decapoda, Brachyura) from Northern and Central-Southern Chile: effects of pre-oviposition temperature and maternal size. Mar. Ecol. Prog. Ser. 377, 193-202.

Food and Agricultural Organization, 2006. The State of World Fisheries and Aquaculture. Food and Agricultural Organization, Rome. 162 pp.

Forward, R.B.J., Tankersley, R.A., Rittschof, D., 2001. Cues for metamorphosis of brachyuran crabs: an overview. Am. Zool. 41 (5), 1108-1122.

Garth, J.S., Stephenson, W., 1966. Brachyura of the Pacific coast of America, Brachyrhyncha: Portunidae. Allan Hancock Foundation; University of Southern California, Los Angeles, Allan Hancock Monographs in. Mar. Biol. 1, 1-151.

Guderley, H., St-Pierre, J.S., 2002. Going with the flow or life in the fast lane: contrasting mitochondrial responses to thermal change. J. Exp. Biol. 205 (15), 2237-2249.

Hankin, D.G., Butler, T.H., Wild, P.W., Xue, Q.-L., 1997. Does intense fishing on males impair mating success of female Dungeness crabs? Can. J. Fish. Aquat. Sci. 54 (03), 655-669.

Hastie, T.J., Tibshirani, R.J., 1990. Generalized Additive Models. Chapman \& Hall/CRC. 335pp.

Heilmayer, O., Brey, T., Poertner, H.O., 2004. Growth efficiency and temperature in scallops: a comparative analysis of species adapted to different temperatures. Funct. Ecol. 18 (5), 641-647.

Heilmayer, O., Thatje, S., McClelland, C., Conlan, K., Brey, T., 2008. Changes in biomass and elemental composition during early ontogeny of the Antarctic isopod crustacean Ceratoserolis trilobitoides. Polar Biol. 31, 1325-1331.
Hobbs, R.C., Botsford, L.W., 1992. Diel vertical migration and timing of metamorphosis of larvae of the Dungeness crab Cancer magister. Mar. Biol. 112 (3), 417-428.

Johnson, J., Shanks, A.L., 2002. Time series of the abundance of the post-larvae of the crabs Cancer magister and Cancer spp. on the southern Oregon coast and their cross-shelf transport. Estuaries 25 (6A), 1138-1142.

Krimsky, L.S., Epifanio, C.E., 2008. Multiple cues from multiple habitats: effect on metamorphosis of the Florida stone crab, Menippe mercenaria. J. Exp. Mar. Biol. Ecol 358 (2), 178-184.

Lehodey, P., Alheit, J., Barange, M., Baumgartner, T., Beaugrand, G., Drinkwater, K., Fromentin, J., Hare, S.R., Ottersen, G., Perry, R.I., Roy, C., van der Lingen, C.D., Werner, F., 2006. Climate variability, fish, and fisheries. J. Climate 19 (20), 5009-5030.

Levinton, J.S., 1983. The latitudinal compensation hypothesis: growth data and a model of latitudinal growth differentiation based upon energy budgets. I. Interspecific comparison of Ophryotrocha (Polychaeta: Dorvilleidae). Biol. Bull. 165 (3), 686-698.

Lonsdale, D.J., Levinton, J.S., 1985. Latitudinal differentiation in embryonic duration, egg size, and newborn survival in a harpacticoid copepod. Biol. Bull. 168 (3), 419-431.

Lovrich, G.A., Thatje, S., Calcagno, J.A., Anger, K., Kaffenberger, A., 2003. Changes in biomass and chemical composition during lecithotrophic larval development of the southern king crab, Lithodes santolla (Molina). J. Exp. Mar. Biol. Ecol. 288 (1), 65-79.

MacKay, D.C.G., 1943. Temperature and the world distribution of crabs of the genus cancer. Ecology 24 (1), 113-115.

Mahalanobis, P.C., 1936. On the generalised distance in statistics. Proc. Nat. Inst. Sci. India 12, 49-55.

Minagawa, M., Chiu, J.-R., Murano, M., 1993. Developmental changes in body weight and elemental composition of laboratory-reared larvae of the red frog crab, Ranina ranina (Decapoda: Brachyura). Mar. Biol. 116 (3), 399-406.

O'Riordan, B., 1998. Peru. El Niño and La Niña. Blowing hot and cold. Samudra Rep. 21, 26-32.

Park, W., Douglas, D.C., Shirley, T.C., 2007. North to Alaska; evidence for conveyor belt transport of Dungeness crab larvae along the west coast of the United States and Canada. Limnol. Oceanogr. 52 (1), 248-256.

Pörtner, H.O., 2001. Climate change and temperature-dependent biogeography: oxygen limitation of thermal tolerance in animals. Naturwissenschaften 88 (4), 137-146.

Pörtner, H.O., Storch, D., Heilmayer, O., 2005. Constraints and trade-offs in climate dependent adaptation: energy budgets and growth in a latitudinal cline. Sci. Mar. 69, 39-55.

Quintana, R., Saelzer, H., 1986. The complete larval development of the Edible Crab, Cancer setosus Molina and observations on the prezoeal and first zoeal stages of C. coronatus Molina (Decapoda: Brachyura, Cancridae). J. Fac. Sci. Hokkaido Univ. 24 (4), 267-303.

Ryther, J.H., 1969. Photosynthesis and fish production in the sea. Science 166, 72-76.

SERNAPESCA, 2006. Servício nacional de pesca. www.sernapesca.cl.

Shanks, A.L., 1986. Vertical migration and cross-shelf dispersal of larval Cancer spp. and Randallia ornata (Crustacea: Brachyura) off the coast of southern California. Mar. Biol. 92 (2), 189-199.

SHOA, 2008. Servicio Hidrográfico y Oceanográfico. Armada de Chile. www.shoa.cl.

Sokal, R.R., Rohlf, F.J., 1981. Biometry - the principles and practice of statistics in biological research. W.H. Freeman, San Francisco, CA. 859pp.

Taggart, S.J., Shirley, T.C., O'Clair, C.E., Mondragon, J., 2004. Dramatic increase in the relative abundance of large male Dungeness Crabs Cancer magister following closure of commercial fishing in Glacier Bay, Alaska. Am. Fish. Soc. Symp. 243-253.

Thatje, S., Heilmayer, O., Laudien, J., 2008. Climate variability and El Niño Southern Oscillation: implications for natural coastal resources and management. Helgol. Mar. Res. 62, 5-14.

Torres, J.J., Childress, J.J., 1985. Respiration and chemical composition of the bathypelagic euphausiid Bentheuphausia amblyops. Mar. Biol. 87 (3), 267-272.

Torres, G., Gimenez, L., Anger, K., 2002. Effects of reduced salinity on the biochemical composition (lipid, protein) of zoea 1 decapod crustacean larvae. J. Exp. Mar. Biol. Ecol. 277, 43-60.

Urban, H.-J., Tarazona, J., 1996. Effects of El Niño/Southern Oscillation on the population dynamics of a Gari solida population (Bivalvia: Psammobiidae) from Bahía Independencia, Peru. Mar. Biol. 125 (4), 725-734.

Weiss, M., Thatje, S., Anger, K., Brey, T., Heilmayer, O., Keller, M., in press. Influence of temperature on the larval development of the edible crab, Cancer pagurus L. J. Mar. Biol. Assoc. UK: (DOI:10.1017/S0025315408003263).

Wolff, M., Soto, M., 1992. Population dynamics of Cancer polyodon in La Herradura Bay, northern Chile. Mar. Ecol. Prog. Ser. 85, 69-81.

Yamahira, K., Conover, D.O., 2002. Intra- vs. interspecific latitudinal variation in growth: adaptation to temperature or seasonality? Ecology 83 (5), 1252-1262. 